\title{
A TRAJETÓRIA DO RISO E DA DANÇA: UMA HISTÓRIA DE ENCONTRO E DE RESISTÊNCIA
}

\author{
K. AGG \\ Universidade Federal do Rio Grande do Norte - Grupo de Pesquisa Estesia \\ aggkatia@gmail.com \\ Submetido 09/09/2016 - Aceito 26/12/2017 \\ DOI: $10.15628 /$ holos.2017.5062
}

\section{RESUMO}

Enquanto manifestações naturais do homem, o riso e a dança apresentam caracteres comuns por serem libertários, subversivos e transcendentais. Também se fortificam na experiência coletiva e difundem o prazer, a alegria e a sublimação. No que compete à dimensão espacial, o riso e a dança dividem o mesmo lugar, chamado corpo e, por isso, foram submetidos à severa vigilância e controle pelos órgãos de poder sociopolíticos. No contexto cênico, ambos podem abraçar a estética cômica e, assim, reorganizam-se perante as muitas maneiras de se manifestarem. A subversão existente no contexto cômico legitima seu poder de libertar e de transformar o indivíduo; denuncia e combate a normalidade; contribui para a construção e expressão de diferentes visões do mundo.

PALAVRAS-CHAVE: cômico, corpo, dança, história, riso.

\section{THE TRAJECTORY OF THE LAUGHTER AND THE DANCE: A HISTORY ABOUT MEETING AND RESISTANCE}

\begin{abstract}
While natural manifestations of man, laughter and dance have common characters because they are libertarians, subversives and transcendentals. They are strengthened with the collective experience and disseminating the pleasure, joy and sublimation. Regarding the spatial dimension, laughter and dance share the same place, called body, and thus, they were subjected to severe surveillance and control by the
\end{abstract}

socio-political power organizations. In the scenic context, both can make use of comic aesthetics and therefore reorganize itself before the many ways to express themselves. The existing subversion in the comic context legitimizes his power to liberate and transform the individual; denounces and combats normality; and it also contributes to the construction and expression of different worldviews

KEYWORDS: body, comical, dance, history, laughter. 


\section{INTRODUÇÃO}

O riso e a dança são manifestações naturais do homem que apresentam caracteres comuns por serem libertários, subversivos e transcendentais. Também se fortificam na experiência coletiva e difundem o prazer, a alegria e a sublimação.

Notadamente, observa-se que a trajetória de ambos apresenta pontos congruentes, uma vez que sempre foram vigiados e controlados pelo sistema sociopolítico. Por outro lado, resistiram com bravura aos juízos de valores aos quais foram (e continuam a ser) expostos, reinventando sua existência ao participar da vida, da arte e da educação da classe humana.

Tanto a dança quanto o riso sofreram perseguições desde a Idade Média, sendo refutados com veemência pelo Cristianismo porque eram associados à prática demoníaca. Apesar de coibidos, eles não deixaram de existir e, com o passar do tempo, foram transformados pelos bons modos aristocráticos, ou seja, foram convertidos em expressões com códigos, posturas e procedimentos coerentes com as regras de comportamento ditadas pela sociedade ocidental desta Era.

A dança medieval conhecida como Carola é um exemplo da resistência à proibição sofrida neste período. Também considerada como a dança da alegria, essa manifestação coletiva ocorria fora do contexto religioso, em ocasiões de cunho festivo e popular. Sua organização se dava em rodas ou fileiras, onde as pessoas se movimentavam com ou sem o contato das mãos.

As classes mais abastadas também se apropriaram dessa dança, mas buscavam se distinguir do núcleo popular. Deste modo, a estrutura da Carola foi transformada pelos aristocratas que se inspiraram na sua estrutura a fim de construir algo mais métrico, conciliando o movimento corporal à musicalidade de maneira mais ordenada, concebendo uma nova estética das formas, pautada na organização do espaço e dos movimentos. Ocorre, então, a diferenciação desta dança, que passa a ser considerada como erudita, em distinção da outra, tida como popular ${ }^{1}$.

A dança, seja de cunho ritualístico, festivo ou popular, foi abarcada pela Igreja na tentativa de purificá-la com vestes sagradas e dogmáticas, adequadas ao doutrinamento do corpo errante, impuro e vão, segundo os parâmetros defendidos por esta entidade de poder.

Assim como a dança, o riso também foi menosprezado pelos filósofos e perseguido pelos teólogos ao longo da Idade Média.

Encontramos em Silva (2006) e em diversos autores ${ }^{2}$, o discurso sobre como a ambiguidade existente no riso era percebida pelos intelectuais na Era Medieval. Seus argumentos se fundamentavam sob dois pontos: o riso defendido enquanto manifestação totalmente humana (menção ao pensamento de Aristóteles ao se referir ao homem como o único animal que ri) e o mito de que "Jesus nunca riu".

\footnotetext{
${ }^{1}$ Para aprofundamento sobre as Danças Antigas, sugerimos a leitura de Bourcier (2006).

${ }^{2}$ Para aprofundamento sobre a Idade Média, sugerimos a leitura de autores como Umberto Eco, Georges Minnois e Jacques Le Boff.
} 
No primeiro argumento, ao homem é conferida certa superioridade em relação aos outros animais. No entanto, o paradoxo que repousa sobre o mito de Jesus vincula o riso à representação da fraqueza humana, inferiorizando a espécie em relação ao divino.

Foi instaurado um forte discurso de rejeição e de condenação ao riso, reforçado pela inexistência de registros que o ligassem ao maior exemplo da humanidade (Jesus, a representação do Humano na tríade cristã) e por sua constante retratação nas mais diversas imagens demoníacas. Ademais, aquele que ria era considerado tolo, vulgar, fraco de caráter, portanto, um indivíduo desprezível para os olhos da Igreja.

Apesar disso, a história do riso nos relata que a sua presença perseverou no contexto extra eclesiástico, inclusive, representando um forte propósito para toda a população na amenização da crise que acometeu o período da Baixa Idade Média, com a dolorosa realidade proveniente da peste e da Guerra dos Cem Anos. Deste modo, sem poder proibir, muito menos exterminar o riso, a Igreja muda seu discurso e o classifica em dois tipos: o riso bom e o riso mau.

O reconhecimento do riso bom ou do sorriso, seria pautado nas suas qualidades de comedimento e discrição. A admissão do riso bom resultaria na domesticação do riso desmedido e barulhento, tido como o riso mau, por sugerir zombaria, disfarce, ardileza e, que continuaria sendo refutado com vigor. Toda a educação aristocrata do período foi pautada sob o prisma desta distinção, sendo as crianças orientadas a serem vistas sorrindo, porém, jamais rindo ou gargalhando.

Por meio deste breve panorama aqui introduzido, observamos que a trajetória do riso apresenta pontos em comum àqueles que também traçam o percurso da dança. Dentre eles, destacamos o corpo, como lugar onde se dá a origem, o abrigo e a expressão destas forças promovedoras da visibilidade do mundo sensível ante a dureza pela qual, muitas vezes, a vida se apresenta.

O homem se apropria das suas faculdades essenciais, transgride normas e reinventa a sua história através dessas duas expressões, as quais promovem a união do caminhar solitário do indivíduo com os seus pares, no exercício pleno da sua funcionalidade social.

\section{RIR: UMA EXPERIÊNCIA COLETIVA}

Provine (2001), relata o episódio ocorrido em 1962, quando no vilarejo de Kashasha, atualmente pertencente à Tanzânia, houve uma avassaladora crise de riso que envolveu em torno de mil pessoas. Em linhas gerais, por um motivo aparentemente banal, três estudantes de um internato de moças riram por horas e seus risos proliferaram rapidamente, acometendo com o passar dos dias, mais de cinquenta por cento das jovens daquela escola. Sem condições de prosseguir com suas atividades educacionais, o internato fechou suas portas, as jovens foram enviadas para suas casas e o vírus do riso se espalhou pelos vilarejos e escolas dos arredores. 0 autor conclui que somente em 1964, dois anos e meio após o seu início, tal episódio conseguiu ser totalmente contido. Para tanto, foram necessárias ações de fechamento de escolas e de impedimento da entrada e saída de pessoas nos vilarejos enquanto alguém estivesse em crise de riso. 
A particularidade do episódio por nós revisitado, reforça dois pontos em relação ao poder do riso: sua ambiguidade, fazendo-nos perceber que nem sempre ele está associado à felicidade ou ao bem-estar; e, seu contágio, também presente em outras manifestações, tais como a tosse, o bocejo e o choro, ainda que em menor escala.

Discorrer sobre o caráter ambíguo, contagiante e corporal que o riso apresenta, reportanos a sua história de perseguição, sofrida principalmente no cerne da doutrina cristã cuja reminiscência é perceptível e atuante ainda em nossos dias, e que comunga com a história do corpo. A tentativa de controle daquele, passa pela domesticação corpórea e, para tanto, a Igreja investe na inclusão do uso do bom riso como estratégia da sua prática educacional.

Gaiarsa (2003) aponta que o processo repressor da alegria e do riso começa sempre na infância. O adulto tende a silenciar a espontaneidade da criança, afinal ele também fora silenciado. Como em um ciclo vicioso, o padrão comportamental somente é reproduzido, sem questionamentos, permanecendo dentro da 'normalidade' social, ou seja, dentro daquilo que é permitido pensar, dizer e realizar, de geração em geração.

Aprendemos que a alegria incomoda, que rir em alto e bom tom é falta de educação, que ri melhor quem ri por último, que dançar é coisa de menina, que existe um jeito certo e bonito de dançar e, assim, reprimimos nossa alegria, nossas emoções, calamos o riso, o choro, o corpo.

Trocamos a espontaneidade do riso que surge por coisas simples pelo riso maquiavélico para provarmos que somos mais espertos ou superiores aos tolos. Rir do outro pode ser permitido, mas não se deve dar motivos para que riam de nós! Tristemente estamos perdendo a capacidade de rir de nós mesmos.

De acordo com Le Goff (2000), o riso é um fenômeno sociocultural, cuja manifestação é mutável segundo a sociedade e o período vivido. Ou seja, sendo o riso um elemento comum entre diferentes sociedades e culturas, os fatores que o desencadeiam bem como sua forma são particulares à cada nicho.

No campo das artes, a coreógrafa alemã Antonia Baehr explorou o riso como temática em uma de suas pesquisas. Dedicou-se ao registro de diferentes sonoridades do riso dentre seus familiares e amigos, posteriormente realizou um denso laboratório para construir partituras sobre as diversas formas, ritmos e gestualidades do rir. Uma pesquisa minuciosa que originou o espetáculo e o livro homônimo, Rir/Rire/Laugh (2008).

Baehr não teve por objetivo a criação de um espetáculo que provocasse o riso, ainda que ele possa acometer a plateia em algum momento por consequência do seu contágio; o foco da coreógrafa se deu no modo pelo qual ele se manifesta, ou seja, na forma do riso propriamente dito.

Seu espetáculo teve como campo de pesquisa a observação de um reduzido grupo social pertencente a suas relações afetivas e, portanto, sintetiza a vivência pessoal da artista. No entanto, é no mínimo curioso nos depararmos ao longo da sua performance com texturas de riso que nos são muito familiares, trazendo-nos à lembrança o riso de pessoas do nosso convívio.

Ao analisarmos esta experiência artística, percebemos que existe uma corporeidade do riso de estrutura comum, que transpõe fronteiras e, por isso, é universal; ao mesmo tempo, 
observamos que ele também tem múltiplas faces, ou seja, apresenta capacidade de expressão com propriedade infinita e particular.

Para a compreensão da singularidade do corpo do riso, lembramo-nos do pensamento de Mauss (2003) que diz que cada sociedade apresenta seus próprios hábitos e, ainda, uma educação para as atitudes corporais. As técnicas do corpo ${ }^{3}$ são montadas no indivíduo, não somente por ele próprio, mas por toda a sua educação, por toda a sociedade da qual ele é parte e conforme o seu lugar de ocupação.

Desta maneira, podemos pensar na utilização do corpo humano nas variadas situações cotidianas ou esportivas e no quanto o nosso repertório de movimento, nosso gestual, nossa postura, retratam as influências conquistadas mediante a história e experiência pessoais.

Neste contexto, a imitação aparece como integrante natural na composição deste repertório. Para o sociólogo francês, seja nos adultos ou nas crianças, a imitação somente ocorre porque existe a admiração de um ato bem-sucedido realizado por alguém que compactua com o imitador de uma relação de confiança ou de autoridade.

No campo da Neurociência encontramos várias pesquisas que endossam possíveis respostas sobre o poder contagiante do riso e o modo pelo qual esse contágio ocorre. Dentre os comportamentos e expressões estudados por pesquisadores desta grande área científica, o riso aparece associado à nossa capacidade imitativa.

A matéria publicada pelo site BBC Brasil, em outubro de 2002, divulga a pesquisa da britânica Campbell ${ }^{4}$, que na ocasião comprovou que a porção cerebral responsável pelo reconhecimento de fisionomias é acionada quando imitamos ou assumimos a expressão de outra pessoa. Logo, tal fato se refere ao princípio de uma espécie de espelhamento de determinadas expressões, ocasionando ações instantâneas de imitação dentre as quais o riso é um exemplo.

Para Dimberg (2000), existe uma relação entre o poder de contágio do riso com a ativação da região cerebral que controla os músculos da face. Ele registrou em seus experimentos a existência de uma maior facilidade na criação de respostas expressivas por imitação do que por oposição às diferentes expressões faciais vistas por seus voluntários em diversas imagens.

Todavia, é fato que, quando rimos fazemos cócegas sonoras no outro e esse movimento desencadeia a proliferação viral do riso. Não é por acaso que humoristas usam o recurso de rir de suas próprias piadas para desencadear o riso na plateia ou ainda que as séries de TV utilizem as laugh tracks ${ }^{5}$ com o mesmo fim.

O riso é um fenômeno expresso no corpo e pelo corpo (Le Goff, 2000, p.72).

\footnotetext{
${ }^{3}$ Compreende-se por técnicas do corpo "as maneiras pelas quais os homens, de sociedade a sociedade, de uma forma tradicional, sabem servir-se de seu corpo" (Mauss, 2003, p. 401).

${ }^{4}$ Leitura completa desta matéria, disponível em: www.bbc.com/portuguese/ciencia/021022 risog.shtml

${ }^{5}$ Laugh tracks - Compreende um recurso muito utilizado em programas audiovisuais, cuja trilha sonora é composta por diferentes tipos de risadas, que também variam em sua intensidade e duração. Ainda que possa ser utilizado com diferentes objetivos, essencialmente, tal recurso tenta recriar um ambiente "interativo", aproximando o telespectador da cena televisiva e despertando o seu riso.
} 
Porém, para viver a experiência do riso, compreendemos que se faz necessário estar disponível por inteiro, ou seja, estar livre dos julgamentos e rótulos instalados no corpo como bloqueadores da capacidade criativa, da capacidade de reinventar a nós mesmos e a vida.

Reportamo-nos aqui, ao riso que se apropria do seu poder edificante na construção de um ambiente salutar, propício ao exercício da partilha de experiências com humor ${ }^{6}$. Ao evocarmos o cômico e suas categorias de humor, seja simplesmente pela via do pensamento, ocorre uma flexibilização corpórea que nos permite perceber, acolher e interagir com o risível.

Freud (1980a) teoriza o humor como desencadeador de um tipo de afrouxamento da vigilante censura interior promovida pelo superego que, ao amenizar seu caráter repressor, permite a expressão do ego de forma lúdica. Segundo o psicanalista, o riso pode ser considerado como uma maneira socialmente aceita de satisfazer às pulsões habitualmente reprimidas, inclusive aquelas de cunho agressivo e sexual, tidas por ele como essencialmente humanas. Portanto, instalados no território do cômico e providos de humor, somos convidados a exercer nosso direito de rir.

Ainda que o ato de rir possa ocorrer através da memória emotiva, ou seja, ainda que o riso permaneça presente no imaginário e renasça após o contexto vivido, reativando as mesmas sensações experimentadas anteriormente, dificilmente rimos quando estamos a sós. $\mathrm{O}$ ato de rir configura um fenômeno essencialmente coletivo.

Essa entidade misteriosa, multifacetada e ambígua, presentifica-se no corpo, pelo corpo e através do corpo, no qual ela ascende e se apropria de maneira gradativa e total. Em uma sociedade que adoece em conjunto, o riso se torna escasso e, progressivamente, tende a ser negligenciado e a desaparecer.

Neste e em outros sentidos, parece-nos importante resgatar a reflexão sobre a sua temática. Ao nosso ver, o riso representa a interação necessária e salutar das relações humanas, porque ele atua na ruptura de fronteiras inter-relacionais, horizontaliza os envolvidos, tornandoos cúmplices no ato da partilha. O riso é reflexão que acolhe, desprende, emancipa e transforma o indivíduo, no âmbito da coletividade.

\section{UMA TRAJETÓRIA DE PRAZER, ALEGRIA E SUBLIMAÇÃO}

A trajetória do riso e da dança é constituída pela criatividade e ousadia humana que lhes concede uma estimada flexibilidade e fluidez no diálogo travado entre eles, ora de maneira mais intimista ora mais remota. Será, portanto, nesse movimento de proximidade e distanciamento que a dança convida o riso a bailar e o riso faz a dança sorrir, rir e, às vezes até gargalhar.

Ambos também estão circunscritos no quadro do bem-estar e do humor, uma vez que elevam o estado de ânimo, provocam autoconhecimento, despertam desejos de mudança, alimentam diferentes visões de mundo, auxiliam no processo de cura...

\footnotetext{
${ }^{6}$ O humor é aqui compreendido como estado de ânimo que facilita o processo de criação de diferentes visões de mundo.
} 
Devemos esclarecer que a menção ao poder curativo do riso e da dança, deve-se ao fato de que abordam o ser humano na sua essência, sem negar a existência do estranhamento, do desiquilíbrio, da seriedade, da insatisfação, do medo. Tratam destas e de outras sensações e emoções, não de modo paliativo, mas de forma contínua e permanente, reorganizando-as através da sensibilização.

Quando desenvolvemos autoconhecimento sensível, adquirimos autonomia, criticidade, amor. Ao nos olharmos com maior amorosidade, observamos o outro e o meio com docilidade, não de modo ilusório ou passivo, mas sim de maneira ativa, sensível, esperançosa.

Neste contexto, temos que nos referir a uma dançarina, cuja arte transpôs fronteiras: Isadora Duncan. Quando lemos os relatos daqueles que tiveram o privilégio de apreciar sua dança, temos a sensação de que nessas ocasiões um diálogo espontâneo e verdadeiro se instaurava entre os corpos da artista e da plateia.

Certa vez, ainda em cena, Isadora disse: Je vais danser la philosophie de ma vie e, no silêncio, sozinha, ela dançou. Sobre esta apresentação, Divoire (1932), que esteve presente na plateia naquela noite, escreveu sobre a dançarina:

Je l'écris sérieusement, fort des confidences que j'ai reçues au long d'une amitié de vingt-deux ans. Isadora ne dansait pas pour la gloire d'être une danseuse applaudie. Elle dansait pour qu'un jour l'Humanité - à laquelle elle croyait - fût plus libre et plus heureuse.

Et l'Humanité, aujourd'hui, n'a-t-elle pas déjà l'âme et le corps plus libres qu'au temps des corsets, des chapeaux-jardins et des fauxs-cols, qu'en ce temps dont rient les jeunes gens d'aujourd'hui, mais dont nous savions rire aussi; comme nous rions encore des petits 1930. (Divoire, 1932, p. 218) ${ }^{8}$

O que nos desperta o interesse neste relato do poeta francês, é justamente o seu caráter atual identificado quando ele menciona que, apesar do passar do tempo, os elementos que coíbem e deformam a liberdade do ser humano continuam a existir, mudando somente a sua roupagem. Apesar disso, a nossa capacidade de rir permanece.

Através da sua dança, Isadora encontrou uma possibilidade de diálogo com a Humanidade. Ela sensibilizou seu público ao construir um subtexto que abordava a liberdade e a felicidade, e por quê não dizer que, desta forma, ela também estabeleceu uma aliança com o riso? Um riso contemplativo, é bem verdade, um sorriso silencioso, interiorizado, mas, nem por isso menor em sua manifestação plena, ativa e reflexiva.

\footnotetext{
${ }^{7}$ Eu dançarei minha filosofia de vida. (Isadora Duncan). In: Divoire, 1932, p.215 - Tradução livre da autora.

${ }^{8}$ Eu lhe escrevi seriamente, pleno de confidências às quais construí ao longo de uma amizade de vinte e dois anos. Isadora não dançava para a glória de ser uma dançarina aplaudida. Ela dançava para que um dia a Humanidade - na qual ela acreditava - fosse mais livre e mais feliz.

E a Humanidade na atualidade, não tem sua alma e seu corpo mais livres do que no tempo dos espartilhos, chapéus de passeio e dos colarinhos falsos, tempo do qual riem os jovens de hoje, mas que nós sabíamos rir também, como ainda rimos das pequenezas de 1930. (Divoire, 1932, p. 218) - Tradução livre da autora.
} 
$\mathrm{Na}$ visão aristotélica, felicidade se relaciona com o estado da alma, o que segundo as palavras da filósofa brasileira Marcia Tiburi ${ }^{9}$ significa a máxima virtude, o melhor jeito de se viver. A escritora ainda pondera que uma vida feliz não é uma vida livre de tristeza, mas uma vida fundamentada na construção de um projeto inspirado na significação daquilo que acreditamos ser o viver.

Talvez a tarefa de quem ama os homens seja fazer rir da verdade, fazer rir a verdade, porque a única verdade é aprendermos a nos libertar da paixão insana pela verdade ${ }^{10}$.

O riso se associa à alegria da partilha, ao estado de satisfação, ao humor, enquanto diferentes maneiras de ver o mundo. Ele nos liberta de um caminho reto e único rumo à felicidade porque atua na reinvenção do sentido que damos à vida, ilustrando as diferentes maneiras e possibilidades de ser, de sentir, de estar, enfim, de viver. E uma das lições deixadas por Isadora nos permite compreender que é perfeitamente cabível assegurar o significado desta mesma sentença, se a reescrevermos modificando o substantivo riso por dança.

Face a toda esta reflexão, algumas questões se despontam: ao longo do nosso século, qual seria o espaço do riso, dentro e fora da cena coreográfica? Podemos relacionar o riso e a dança contemporânea? Como a dança se encontra no quadro da comicidade? Existem diferentes categorias cômicas no contexto da dança contemporânea? Rir provoca a dança ou a dança provoca o riso?

Tais questionamentos não ousam clamar respostas prontas, mas buscam a felicidade existente na reinvenção dos possíveis e intermináveis diálogos sobre/entre o riso e a dança.

\section{ENCONTRO E RESISTÊNCIA}

Quando revisitamos a trajetória histórica da humanidade, deparamo-nos com uma marcha engajada na necessidade de dar voz, corpo e expressividade às diferenças. $O$ homem reaprende a lutar, vence ditaduras, conquista espaço nas ruas, grita por seus direitos, silencia pela morte de inocentes, brada pela liberdade de viver sua crença, seu sexo, seus valores.

Esta marcha humana nos possibilita a coleta de ensinamentos, que mensurados ora em pequenas ou grandes conquistas ora em pequenas ou grandes perdas, reporta-nos ao sempre atual, dinâmico e longo caminho do aprimoramento.

Neste aspecto, para vencer as mazelas e não desanimar durante a caminhada, os discursos motivacionais podem ser válidos enquanto alavanca para a engrenagem do motor principal: a automotivação. Muito embora este percurso seja individual, sua força nasce do contato, do encontro, da partilha, ou seja, no exercício da coletividade. Apesar de paradoxal, a experiência coletiva é determinante para o entendimento daquilo que é particular. $O$ viver em comunhão reitera o poder da diversidade e da transformação.

\footnotetext{
${ }^{9}$ Vídeo da SaraivaConteudo (2014), disponível em www.youtube.com/watch?v=W_1EtLeJEh0

${ }^{10}$ Fala do personagem Guilherme de Baskerville (Eco, 2003, p. 470). In: SILVA, 2006, p. 5.
} 
Quando o indivíduo está inserido em um grupo social, suas ações comunitárias são reconhecidamente potencializadas; o coletivo empodera o individual e esse poder se propaga também através dos sentimentos que o mobilizam. Em grupo, gritamos mais, dançamos mais, reivindicamos mais, cantamos mais, comemos mais, criamos mais, rimos mais. Exatamente por expirar tamanha força, torna-se fácil imaginarmos que os interesses das diversas ordens sociopolíticas façam uso de um jogo sedutor e manipulador para que possam manter sob controle o brio da coletividade.

Mediante este jogo de alto risco, cujo cenário é protagonizado pelos poderes sociopolíticos e econômicos, o interesse em propagar e controlar as ideias e os sentimentos é demasiadamente perigoso enquanto estratégia de manobra. Neste caso, a massificação, o fanatismo e a idolatria por um líder e/ou por uma causa tida como igualitária, desnudam o indivíduo de liberdade e de autonomia. Enfraquecido e cegamente rendido pelo discurso propagado, ocorre a perda de si mesmo, ou seja, o indivíduo deixa de ser o 'sujeito' das ações para se tornar o 'objeto' a ser manipulado de acordo com a vontade do poder do grupo.

Temos amplos exemplos desta ordem que são capazes de demonstrar como determinados padrões de pensamentos e/ou sentimentos, quando levados a um nível exacerbado, levaram (e ainda levam) certos nichos sociais a cometerem ações impensadamente brutais, desumanas, porque foram (e ainda são) calcificadas no ódio, no desprezo, no pavor, no desconhecimento, na intolerância, no preconceito ${ }^{11}$.

Esta pretensão de controlar e alienar a sociedade, parece-nos estar também associada a ideia de desconstrução da imagem daquilo que é positivo, ao evidenciar os aspectos invertidos da mesma unidade, ou seja, ocorre a deturpação daquilo que se quer desconstruir, ocultar ou aniquilar, por meio da imposição de um juízo de valor, seja este de qualquer ordem.

Imersa na contemporaneidade, período pleno de ambiguidades e discursos transitórios, a humanidade assiste à queda de verdades, muitas das quais embasam a sua existência, ao mesmo tempo em que participa da reconstrução paradigmática de diversos conceitos, em especial àqueles relacionados à tríade tecnologia/homem/meio ambiente.

Parece-nos que o homem, instigado ou não pelas heranças provenientes das grandes guerras, traz em seu âmago a relação voraz entre a vida e a morte. Essas seriam duas instâncias das quais não se pode escapar. O tempo que separa um ponto do outro é inexato, portanto, a brevidade, a urgência, a intensidade, o medo são alguns dos substratos que dão ênfase a sua permanência na terra e estes se alimentam através dos modos de vida pertinentes a cada sociedade de cada época.

Dialogando com dramaturgos, diretores e pesquisadores das artes cênicas, Naugrette (2004) pontua que apesar da Europa possuir um contexto político democrático, onde a liberdade

\footnotetext{
${ }^{11}$ O enredo trazido pelo filme alemão $A$ Onda, de Gansel (2008) nos faz refletir sobre esta questão: a carismática liderança conduzida pelo professor de história de uma escola, entusiasma e reverbera o fanatismo trazido por ditames que fomentam o sentimento xenofóbico em um grupo de estudantes. A situação se alastra por toda a escola, cujos jovens perdem o controle de seus próprios pensamentos, compactuando e agindo cegamente de acordo com as regras do movimento d'A Onda.
} 
de opinião ou de religião são inscritas na constituição, o desaparecimento do riso surge como um fato a ser constatado dentro da realidade do teatro ocidental moderno.

En France, nous ne vivons pas en dictature, les rieurs ne sont pas pourchassés, on peut écrire librement, les théâtres recherchent toujours de nouvelles pièces, le public souhaite s'amuser. Toutes les conditions sont réunies, en apparence, pour que triomphe la comédie. Et paradoxalement, le genre est en péril: on dirait une espèce en voie de disparition ${ }^{12}$. (Nichet apud Naugrette, 2004, p. 34)

A autora ainda pondera e concorda com o cineasta Jacques Nichet quando o mesmo diz que a dificuldade ou incapacidade da comédia em dar conta da eclosão do mundo atual, seria um dos fatores responsáveis pelo seu desaparecimento. O riso de Aristófanes ou de Molière despertava prazer e iluminação em seus espectadores, ainda que tivessem a intenção de denunciar e combater as injustiças da sociedade e os vícios dos homens. Na atualidade, a compreensão da violência e das mazelas do século são compreendidas através da nossa tendência à tristeza.

Se, como diz Nichet citado por Naugrette (2004), a comédia é escrita para triunfar também sobre o medo, dentre eles, o medo da morte, a chaga tatuada na humanidade principalmente com o Holocausto, não permite que esqueçamos que uma civilização inteira pode morrer. Deste modo, o riso triunfante e salvador se perde, fazendo com que nos percamos um pouco mais de nós mesmos.

Neste contexto, as artes tiveram e tem papel crucial no resgate e na proliferação de expressividades e de corpos diversos, uma vez que, tendo sido os artistas afetados pelos acontecimentos locais e mundiais, os mesmos também afetaram o meio com suas respostas criativas, atemporais e sem fronteiras.

Se é atual a discussão acerca do desaparecimento do riso das cenas do teatro ocidental moderno, na dança contemporânea observamos de modo igualmente efetivo a ocorrência de uma absorção cênica cada vez maior dos nutrientes da comicidade.

Ao mencionarmos a aproximação da dança, em especial da dança contemporânea com o cômico, podemos causar estranhamento e, inclusive, risos. Sendo a dança contemporânea conhecida por sua linguagem séria, introspectiva, abstrata, crítica, parece-nos que nela, à primeira vista, não existe espaço para o cômico e, consequentemente, para o riso.

No período em que realizamos nossa pesquisa em território francês, pudemos constatar que a partir da década de 1980, com a ascensão do movimento da Nouvelle Danse Française, o cenário técnico-poético da dança absorve novas tendências que serão significativas para uma outra escrita coreográfica.

\footnotetext{
12 Não vivemos em ditatura na França, aqueles que riem não são hostilizados, pode-se escrever livremente, o teatro sempre procura novas peças, o público deseja se divertir. Aparentemente, todas as condições estão reunidas para que a comédia triunfe. Paradoxalmente, o gênero está em perigo: pode-se dizer uma espécie em via de desaparição. (Nichet, p. 306 apud Naugrette, 2004: 34) - Tradução livre da autora.
} 
Em um primeiro momento, ocorre a emergência daqueles elementos que tornar-se-iam as marcas desta linguagem artística, tais como a ruptura com a narrativa, com a música, com toda e qualquer artificialidade cênica; e a promoção do experimental, do contato com o corpo na sua forma bruta, com sua essência, com sua natureza.

Posteriormente, empoderada pelas conquistas político-culturais adquiridas no período, a dança autoral, como também é conhecida a Nouvelle Danse Française, passa a redefinir-se e desenha seu próprio perfil, no qual observamos que os aspectos do cômico se fazem presentes.

Isso não significa que a dança contemporânea francesa seja exclusivamente cômica, mas sim que ela apresenta uma estética que toca o cômico em suas diversas categorias. Tal fato, a aproxima da experiência do riso, seja este contemplativo, como em Groosland (1989), de Maguy Marin, onde a plateia participa da vida e dos sentimentos de um grupo de obesos; seja um riso empático, como na paródia de Carmen (1992), de Dominique Boivin ${ }^{13}$.

A relação da dança com o cômico não é algo atual. Na verdade, esta parceria secular se inicia por volta do final do século XVI, conforme registros históricos. O principal registro do período, refere-se ao Ballet Comique de la Reine, primeiro ballet de corte encomendado por Catharina de Médicis e que fora criado no ano de 1581.

Além da referência ao cômico estar presente no próprio título da obra, traços do grotesco (uma das categorias do cômico) podem ser observados neste ballet devido aos seus personagens mitológicos, portadores de corpos híbridos e disformes, compostos por membros de humanos e de outros animais, como as Sereias, os Tritões (deuses, filhos de Poseidon, habitantes do fundo do mar) e os Sátiros. O fato de serem personagens nobres ou divinos, representa outra marca da estética do grotesco que, neste período, almeja camuflar e suavizar a presença cômica.

A transformação do corpo em cena através do uso de máscaras e figurino, torna-se um dos recursos a contrastar a dança séria e a dança cômica, permitindo o desencadear do humor e o nascimento do riso. Ocorre, portanto, uma transformação sistemática que vai além do corpo dos artistas em cena, ou seja, a metamorfose acontece no corpo da dança em si.

Se o sublime tem uma face, enquanto que o grotesco tem mil faces, como escreveu Hugo (2007), a dança contemporânea não seria justa com ela própria se deixasse fora de cena a inteligência do cômico. Apropriando-se do grotesco, do burlesco, da parodia, enfim, ao trazer as faculdades do cômico para o seu contexto, a dança contemporânea se revela empoderada de humor, por isso, representa ser uma chave imprescindível para a criação de diferentes visões de mundo.

Seja através da sua história marcada por encontros ou por resistências, a dança contemporânea reescreve a sua narrativa, utilizando-se dos aspectos lúdico e sensível do humor; dos aspectos pedagógico e carnavalesco do burlesco; da polêmica ambiguidade do grotesco; da

\footnotetext{
${ }^{13}$ Maguy Marin e Dominique Boivin são coreógrafos da primeira geração da Nouvelle Danse Française, assim como Mathilde Monnier, Philiphe Decouflé, dentre outros. Atualmente, todos continuam ativos no exercício da arte coreográfica. Esclarecemos que eles não são coreógrafos cômicos, mas podemos encontrar em seus repertórios algumas obras coreográficas de estética e linguagem cômicas.
} 
dissimulação e da sutileza da ironia. Em constante diálogo com a seriedade e a alegria, a dança vai se traduzindo, reinventando-se à sua própria maneira.

\section{O PODER DO MOVIMENTO}

Se rir é um dos quesitos essenciais aos seres humanos, não podemos deixar de citar, pelo menos mais um deles: o toque. Montagu (1988) fomenta esta temática, sempre importante e atual. Dentre as assertivas apresentadas pelo autor, encontramos a referência de que o contato em humanos (e nos animais), quando ainda bebês (e filhotes), corroboram com a melhoria da saúde, do estado de atenção e da devolutiva de respostas ao meio.

Se pensarmos o toque de maneira expandida e sem atuações sensoriais fronteiriças, podemos considerar o olhar como uma forma de contato, logo, um toque em potencial. Quando olhamos o outro, repousamos nossos sentidos, nossas intenções, nossos sentimentos na sua pele. O outro por sua vez, percebe e reage ao toque, retribuindo-o com seu olhar.

Assim, podemos dizer que o olhar e o abraço fazem parte de uma mesma categoria, cuja maior congruência se dá no momento exato do encontro, do contato, da fusão dos toques que elabora, infla e sacraliza esta unificação. Quem abraça quem? Quem olha quem?

Vale ressaltar, que estamos aqui nos referindo ao toque sem conotação de apelo sexual, ou seja, reportamo-nos ao toque que se faz presente de corpo inteiro na partilha da comoção, da alegria, da esperança, do conforto, da cumplicidade, da carícia que não tem alusão à sedução ou ao prazer sensual.

Podemos analisar o riso e a dança sob esta mesma perspectiva: um sorriso franco ativa outro sorriso; já na manifestação da dança, esse encontro ocorre através da experiência estética, ou seja, no diálogo sinestésico partilhado entre a plateia, o artista e a obra. Em ambas manifestações, o contato salutar, intensifica e ressignifica o corpo, o contexto, as percepções, as ideias dos envolvidos.

Uma vez mais, o riso e a dança se relacionam e interagem com o coletivo, despertando o imaginário, desconstruindo paradigmas, atuando na depuração da essência humana, cuja reorganização sensível se assemelha ao que Deleuze e Guattari (1996) chamam de corpo sem órgãos (CsO).

Capaz de expurgar fluídos com validade vencida, o riso coloca o corpo todo em movimento, acionando todo o sistema fisiológico e muscular, fato que nos beneficia incondicionalmente.

Durante e após o ato de rir, o corpo se beneficia dos efeitos similares àqueles promovidos pela atividade corporal do dançar. Os órgãos internos são fortalecidos através do trabalho de contração e relaxamento muscular; a sensação de bem-estar é favorecida seja pela inibição de hormônios associados ao stress, como o cortisol, seja pela produção de endorfina, considerada um analgésico natural porque desencadeia sensações de relaxamento e de minimização da dor. 
Ainda, proporciona considerável redução de tensão através da expiração porque colabora com o processo de eliminação dos elementos nocivos do organismo, como o dióxido de carbono acumulado, sobretudo, nos espaços articulares.

Se fizermos um rápido exercício de percepção, atentando-nos aos dois momentos que constituem a respiração, possivelmente, iremos perceber que a inspiração é mais prolongada do que a expiração. Analogamente, podemos notar que absorvemos as materialidades do meio, muitas vezes, com demasiada ansiedade em capturar tudo o que nos falta. No entanto, a devolutiva ao meio dificilmente acontece com a mesma proporção, afinal, apresentamos uma tendência em sermos acumuladores.

Sob este prisma, o riso representa a possibilidade do desapego daquilo que está retido e/ou perdido dentro de nós porque anima e coloca em fluxo a expressividade e, através da respiração, do som, do movimento corporal, materializa-se e comunica. De maneira leve e consistente, funciona como uma válvula de escape, possibilitando o desatar das amarras invisíveis, provocando alívio àquele que o vivencia.

Estou falando de rir de alegria, rir porque é engraçado, rir porque as coisas se combinam, às vezes, das maneiras mais surpreendentes.

Nesse sentido, o riso está muito próximo da criatividade. Quem é muito sério tende a ver as coisas sempre do mesmo jeito - com a mesma cara! É o caso do preconceituoso, para o qual certas situações ou pessoas significam sempre a mesma coisa - e só aquilo. Claro que assim a vida não tem graça nenhuma! Já quem tem facilidade de rir, facilmente se desenquadra ou desencaixa de situações difíceis, e consegue depois vê-las e resolvê-las de outra maneira. [...]. Ao contrário do povo, segundo o qual muito riso é pouco siso, eu diria que muito riso é um sinal de que não estou ligado a nada, preso a nada, fixado a nada, que eu gozo, em suma, de um alto grau de liberdade. (Gaiarsa, 2003, pp. 101-102)

Comungamos com Gaiarsa (2003) o sentido que damos ao riso, uma vez que acreditamos que ele seja salutar quando nasce da espontaneidade, da alegria, da liberdade, ou mesmo, da reflexão. Porém, o mesmo se torna insalubre e perigoso se nascer em prol da difamação do outro ou, ainda, com o propósito de nutrir o preconceito.

Por outro lado, a ambiguidade que ele aporta é perturbadora, afinal, quem ri: rende e é rendido; seduz e revela que foi seduzido; abre ou fecha portas. Pensando nos preceitos que pairam em nossa sociedade, cujas relações e discursos são pautados na seriedade, existem diversos ditos populares quase transformados em mantras diante daquele que ri: Muito riso, pouco juízo! Pelo riso se conhece o tolo! Fazer rir, é fazer esquecer! Quem ri muito, não é digno de confiança. Como confiar em alguém que encontra motivos (e tempo!) para rir, se a vida é tão séria, triste, difícil, problemática, dolorosa, injusta, fugaz?

Vincula-se, ainda, à imagem do descontrole, do estado alterado induzido ou não por substâncias alucinógenas, ao imaginário do malévolo, do diabólico, por isso, rir fora da medida padronizada e aceita como normal e de bom tom, provoca estranhamento e certo temor, inclusive. 
Porém, do que rimos? O que é risível? Como rir de corpo inteiro? O riso é uma forma de expressão, onde queremos comunicar, onde existe o desejo da partilha. As motivações e as formas do riso variam de acordo com a sociedade, o período e a cultura, o que reflete o diferente humor de uma nação, a sua subjetividade. O riso é, de fato, um fenômeno particular: não rimos de tudo, nem com todos, nem o tempo todo. Porque rir é preciso, já o risível não é preciso...

Dançamos e rimos do/com o outro e de/com nós mesmos, não para aumentarmos a diferença ou para enfatizar uma suposta superioridade, tampouco para enfatizar preconceitos. Nós o fazemos como um convite à celebração da vida tal como ela é, com todas as suas diferenças, de modo mais leve, espontâneo e alegre. Através do riso e da dança podemos encantar, chocar, expressar, partilhar, (re)criar.

\section{CONSIDERAÇÕES FINAIS}

Como pudemos analisar ao longo deste artigo, a trajetória do riso e da dança se constrói pela criatividade e ousadia humana que Ihes concede flexibilidade e fluidez em seus caminhos individuais e também quando estes se encontram e dialogam.

Ambos se subscrevem tanto no quadro do bem-estar quanto do humor, modificando e/ou reafirmando o estado de ânimo do indivíduo, corroborando com seu autoconhecimento e com o despertar de desejos por mudança. Enquanto elementos atuantes no processo de cura, a dança e o riso ressignificam conceitos, histórias e lugares porque alimentam diferentes visões de mundo.

Quando desenvolvemos autoconhecimento sensível, adquirimos autonomia, criticidade, amor. Ao nos olharmos com maior amorosidade, observamos o outro e o meio com docilidade, não de modo ilusório ou passivo, mas sim de maneira ativa, sensível, esperançosa.

O riso é uma manifestação emotiva que transborda, que salta aos olhos (e ouvidos), ocupando e transformando o espaço sem discrição. Ele se apresenta como uma manifestação coletiva que ganha forças no encontro com outro riso, e por isso, agiganta-se na espacialidade sonora, na expressividade corporal daquele que ri.

Observamos ainda que, dentre os elementos congruentes que compõe a trajetória do riso e da dança, destaca-se o corpo. O corpo que é o lugar onde se dá a origem, o abrigo e a expressão destas forças promovedoras da visibilidade do mundo sensível ante a dureza pela qual, muitas vezes, a vida se apresenta.

Diversos são os elementos que conferem a estas duas manifestações histórias de encontro e resistência; empoderamento, alegria e transformação. Tanto a dança quanto o riso, cada qual à sua maneira, resistiu à retalhação sofrida, sobretudo na Idade das Trevas. Ainda que tenham herdado resquícios deste período, continuam a escrever sua história com seriedade e humor.

Tal e qual uma criança travessa, o homem se apropria das suas faculdades essenciais, transgride normas e reinventa a sua história através dessas duas expressões. 
A dança não corre atrás do riso, tão pouco o riso existe por causa da dança. Porém, ambos se encontram, associam-se e dividem suas histórias de perseguição, de expressão, de poder transformador. Eles se misturam na poética narrativa construída na fusão obra/artista/plateia.

No percurso da sua trajetória contínua, ter consigo a companhia do riso, seja enquanto motor cênico ou enquanto manifesto dentre àqueles que a contemplam, permite a dança maior versatilidade comunicativa, uma vez que esta mobilidade capacita o aproveitamento dos saberes e dos sabores fundamentado na atmosfera do humor e do cômico.

A subversão existente no contexto cômico é legítima e passível de realização expressa na dança conforme o subtexto coreográfico, estabelecendo relações de poder, de liberdade e de transformação.

\section{REFERÊNCIAS}

Bergson, H. (1983). O RISO. (N. C. Caixeiro, Trad.). RJ: Zahar Editores SA.

Bremmer, J., \& Roodenburg, H. (2000). Uma história cultural do humor. Rio de Janeiro: Record.

Bourcier, P. (2006). História da Dança no Ocidente. São Paulo: Martins Fontes.

Deleuze, G. \& Guattari, F. (1996). Mil platôs. Capitaismo e Esquizofrenia. (Vol. 3). (A. Guerra Neto, Trad.). RJ: TRANSEDITORA34.

Divoire, F. (1932). La révolution d'Isadora Duncan. In: Berton, C. \& Boll, A. (Orgs.). Les spectacles, a travers les ages - Musique. Danse. vol. II. Paris: Aux éditions du Cygne, 215-234.

Freud, S. (1980a). Os chistes e sua relação com o inconsciente. Obras completas, ESB, v. VIII. RJ: Imago.

Freud, S. (1980b). O humor. Obras Completas, ESB, v. XXI. Rio de Janeiro: Imago.

Gaiarsa, J. A.(2003). Minha Querida Mamãe. SP: Editora Ágora.

Hugo, V. (2007). Do grotesco e do sublime. (C. Berretini Trad.). SP: Perspectiva.

Le Goff, J. (1989, Mars). Rire au Moyen Age. Cahiers du Centre de Recherches Historique, École des Hautes Études en Scienses Sociales [En ligne]. Mis en ligne le 14 mars, 2016 de https://www.ehess.fr/fr

Mauss, M. (2003). Sociologia e antropologia. São Paulo: Cosac e Naify, 401-422.

Minois, G. (2003). História do riso e do escárnio. São Paulo: Unesp, 111-145.

Montagu, A. (1988). Tocar: o significado humano da pele. (M. S. M. Netto, Trad.). SP: Summus.

Naugrette, C. (2004). Paysages dévastés - Le théâtre et les sens de l'humain. France: Circé.

Provine, R. (2001). Laughter, a Scientific Investigation. United States: Penguin USA.

Silva, A.O. da. (2006, Março). Entre o sagrado e o profano: o interdito ao riso. [Versão eletrônica]. Revista Espaço Acadêmico. XX (58), pp. 1-5. Recuperado em 14 de março, 2016, de http://www.espacoacademico.com.br/058/58ozai.htm 